\title{
Alexandra Bamji, Geert H. Janssen and Mary Laven (eds.)
}

The Ashgate Research Companion to the Counter-Reformation. Farnham, Surrey and Burlington, Vermont: Ashgate, 2013. Pp. 508. Hb, £85.00.

Over the past thirty years scholars working in a number of different specialties have collectively transformed our understanding of early modern Catholicism. Efforts to impose unity on the Catholic world have largely been put to one side in recognition of the variety of ways that Catholics across the globe experienced their faith. Earlier emphasis on top-down reform through Trent, the papacy, the inquisition, and the new religious orders has been contextualized in a broader conception of change which gives greater weight to the agency of the laity through the activities of lay patrons, families, groups, and corporations. With this re-evaluation has come a new organizational framework for the field based on a longer chronology that stretches well into the eighteenth century, and a geographical scope that both places greater emphasis on the Catholic faith outside its traditional heartlands in southern Europe and also recognizes that overseas expansion not only transformed those regions that were evangelized but also had a profound impact on Catholicism in Europe.

This welcome volume sketches the new contours of the Counter Reformation in twenty-four chapters, each written by a leading scholar in the field. These contributions are split into four parts. Part one, entitled "Conflict, Coexistence and Conversion" explores these three central themes in turn. Chapters on Tridentine Catholicism, confessionalization, and the inquisition explore how recent scholarship has engaged with and altered our thought on institutions engaged in the top-down reform of society. Two chapters devoted to religious coexistence and the experiences of Catholic exiles shift the focus to the relatively new interest in efforts of Catholics to negotiate the multi-confessional environments of post-Reformation Europe. Finally, three chapters on Catholic pamphleteering, missions to Asia, and missions to the Americas explore evangelization in the new contexts of printing and overseas expansion.

Part two, "Catholic Lives and Devotional Identities," explores what might broadly be termed the varied experiences of lay Catholics. Chapters on being Catholic in early modern Europe and the Catholic life cycle examine the experiences of the Catholic laity through lenses that have traditionally been used to study Protestants. Three further chapters on the sacred landscape, sanctity, and the senses explore important current fields in the study of religious experience and practice. Finally, two chapters, one on lay spirituality and the other on piety and community, focus on collective aspects of religious life. Comprised of six chapters, part three, "Ideas and Cultural Practices," explores 
in turn intellectual culture, science, music, drama, art, and material culture in the early modern Catholic world. In each case these topics, which are frequently the subject of specialist study, are consciously placed in the wider context of the Catholic Reformation. Finally, part four, "Religious Change," seeks to contextualize the Counter Reformation in broader geographical and temporal frames. Thus one chapter focuses on the globalization of the Catholic faith, while another considers the Counter Reformation from a medieval perspective, and a third considers the modern legacies of the Counter Reformation.

Each contribution to the volume adheres to a well-conceived structure. Chapters open by laying out the current state of the field with special attention paid to points of debate and the relationship of more recent scholarship to older schools of thought. Then each author focuses on a specific topic or topics related to his or her own research that cast light on current developments in the field. Chapters conclude with an up-to-date bibliography providing an accessible entry point for those seeking to explore the topic further. Averaging less than twenty pages, these chapters are admirably brief and yet wide ranging.

As one might expect, the Society of Jesus features prominently in the volume. The entry for "Jesuits" in the index is split into fifteen sub-headings recording some 150 page references. This prominence reflects the Society's contribution to so many facets of early modern Catholicism, from overseas missions and education to drama, music, and science. Taken collectively, the prominence of the Jesuits in these twenty-four chapters reminds us of the Society's important contributions to many critical aspects of early modern Catholic culture. While recognizing the accomplishments of scholars who study the Jesuits, some contributors express concern that research focused on the Society has become too dominant in some fields, obscuring a more complex reality. Tara Alberts, writing on missions to Asia, notes that "The Jesuit articulation of 'accommodation' and the implementation of this approach were undoubtedly highly innovative. Yet to some extent this focus on Jesuit strategies has obscured the techniques tried by missionaries of other religious orders to present themselves in a culturally appropriate way" (137). Similarly, when reflecting on Catholic science, Nick Wilding notes that "The Jesuits have been made to represent Catholic science, with the result that their own position and motivation within a larger field has been obscured" (333). These comments among others point to a perceived need to better contextualize the activities of the Jesuits in future research.

The absence of chapters dedicated to traditional subjects like Trent, the papacy, and new religious orders reflects this volume's approach to the field 
and in many ways this new organization better contextualizes these institutions in broader developments than their traditional treatment as separate topics. One could make the case for the addition of further topics in line with new approaches to the concept of Counter Reformation, including a chapter on education and another on political thought, especially the question of sovereignty which had a profound impact on the relationship between church and state across the Catholic world during the period. But in many ways such a criticism is unfair. The volume does not claim to be encyclopaedic and is already nearly 500 pages in length. It provides a welcome introduction to the most recent research on the Counter Reformation for undergraduate and graduate students and a useful and accessible survey of a rapidly changing field for advanced scholars.

Eric Nelson

Missouri State University

EricNelson@missouristate.edu 